Reprod. Nutr. Dévelop., 1981, 21 (1), 103-108.

\title{
Plasma dopamine-beta-hydroxylase and platelet monoamine oxidase activities in pigs with different susceptibility to the malignant hyperthermia syndrome induced by halothane
}

\author{
par R. DANTZER ${ }^{1}$, F. HATEY ${ }^{2}$ \\ with the technical assistance of R. M. BLUTHÉ \\ Station de Pharmacologie, I.N.R.A., \\ 180, Chemin de Tournefeuille, 31300 Toulouse, France.
}

Summary. Plasma DBH and platelet MAO activities were measured by radioenzymatic assay in 10 Large-White and 20 Piétrain pigs 9 to 11 weeks old. Piétrain pigs within the same litter, challenged by halothane, were classifed as malignant hyperthermia $(\mathrm{MH})$ susceptible or not according to their reaction. The Large-White pig strain was not susceptible to $\mathrm{MH}$.

Plasma DBH activity did not differ according to strain or to $\mathrm{MH}$ susceptibility. Platelet MAO was lower in Large-White pigs but was not affected by MH susceptibility in Piétrain pigs.

The results do not confirm any nervous differences in MH-susceptible pigs.

\section{Introduction.}

When some pigs are exposed to the anesthetic agent, halothane, they develop abnormal metabolic reactions characterized by muscular rigidity, hyperthermia and metabolic acidosis, leading to death within a few minutes unless the anesthetic is withdrawn. This pathological condition in pigs has been used as a model to investigate sensitivity to stress and the production of pale, soft, exsudative pork (Dantzer and Mormède, 1979). Although primarily related to abnormal calcium movements in mitochondria of skeletal muscle (Cheah and Cheah, 1976), malignant hyperthermia $(\mathrm{MH})$ has also been suggested to be a generalized stress syndrome involving functional abnormality of the sympathetic nervous system. It has been debated whether the sympathetic nervous system primarily contributes to $\mathrm{MH}$ or whether the sympathetic response is only secondary to the metabolic changes concomitant to $\mathrm{MH}$. Most studies have been indirect using adrenergic agonists and antagonists (for recent review see Lucke ef al., 1979).

(1) Address reprint requests to : Laboratoire de Neurobiologie des comportements, Université Bordeaux II, 146 rue Léo-Saignat, 33076 Bordeaux cedex, France.

(2) Present address : Station de Génétique cellulaire, INRA, Chemin de Borde Rouge, 31320 Castanet Tolosan, France. 
Only a few data are available concerning the biochemical factors of sympathetic function in $\mathrm{MH}$-susceptible pigs. Plasma catecholamine levels have been reported to be normal (Althen et al., 1977) or higher (Williams ef al., 1978) in MH-susceptible pigs. The main problem in the interpretation of plasma catecholamine levels arises from the difficulty of defining the baseline levels and normal values. The lack of proper controls is another problem since divergencies between strains have been confused with differences in $\mathrm{MH}$-susceptibility. As a matter of fact, a very different approach combining behavioral and neuro-endocrine measurements has shown that $\mathrm{MH}$ susceptibility, in contrast to inter-strain differences, has no nervous correlates (Dantzer and Mormède, 1978 ; Mormède and Dantzer, 1978).

The present work presents a preliminary investigation of some biochemical factors of sympathetic function in $\mathrm{MH}$-susceptible pigs and control pigs from the same strain and from a different strain. We studied the activities of two enzymes playing a key role in the metabolism of catecholamines : dopamine-beta-hydroxylase (DBH) which converts dopamine to noradrenaline, and mono-amine oxidase (MAO), a mitochondrial enzyme which catalyzes the oxidative deamination of dopamine, norepinephrine, serotonin and other biogenic amines. Because it is present in the granular vesicles which store noradrenaline and is discharged by exocytosis, $\mathrm{DBH}$ has been suggested as a marker of sympathetic activity (Geffen, 1974). MAO occurs in the blood platelets of some species, including man, so that its in vivo activity can be conveniently studied. Alterations in MAO activity have been reported in association with a number of behavioral disorders in humans and animals (e. g. Murphy and Wyatt, 1972 ; Redmond et al., 1979). As expected from our previous work (Dantzer and Mormède, 1978 ; Mormède and Dantzer, 1978), the results of the present study demonstrate that differences in enzyme activities are found only between strains and not in MH-susceptible pigs.

\section{Material and methods.}

Ten Large-White pigs ( 5 females and 5 castrated males) from a strain reacting negatively to halothane and 20 Piétrain pigs ( 11 females and 9 castrated males) from a strain selected for meatiness were used. Both strains were kept at the Department of Animal Genetics (Domaine expérimental de l'INRA, Avord).

At 9 to 11 weeks of age, the Piétrain pigs were tested for halothane susceptibility as described by Ollivier ef al. (1975). The test was stopped when rigidity in the rear limbs was observed or after 5 min had elapsed with no evident rigidity.

Just before halothane screening, $10 \mathrm{ml}$ of blood were withdrawn from each pig by puncture of the vena cava. All the blood samples were collected in plastic tubes containing $0.19 \mathrm{ml}$ of $0.25 \mathrm{M}$ EDTA in $0.1 \mathrm{M}$ phosphate buffer, $\mathrm{pH} 7.4$ with $0.9 \mathrm{p} .100 \mathrm{KCl}$. The platelets were obtained by repeated centrifugation of platelet-rich plasma as described by Winter et al. (1978). Plasma and platelets were stored frozen at $-20^{\circ} \mathrm{C}$ until biochemical assay.

Plasma DBH activity was measured in duplicate according to the radioenzymatic assay described by Bouclier ef al. (1977). Enzyme activity was detected by converting ${ }^{2-14} \mathrm{C}$-tyramine to $2-{ }^{14} \mathrm{C}$-octopamine which was then subjected to periodate cleavage to form ${ }^{14} \mathrm{C}$-hydroxybenzaldehyde. DBH activity was expressed as the amount of 
p-hydroxybenzaldehyde formed per $\mathrm{ml}$ of plasma per hour. Incubation was carried out for $45 \mathrm{~min}$. Preliminary assays showed that $10^{-3} \mathrm{M} \mathrm{CuSO}_{4}$ (final concentration) was the optimal concentration for determining DBH activity in pig plasma. Such a high concentration was required because EDTA was used as the anticoagulant agent.

Platelet MAO activity was measured in triplicate using a modification (Winter ef al., 1978) of the radioenzymatic assay originally described by Wurtman and Axelrod (1963) with tryptamine as the substrate. MAO activity was expressed as the amount of labeled deaminated metabolites formed per $\mathrm{mg}$ of platelet protein per hour. Incubation was carried out for $1 \mathrm{hr}$.

Fumaric acid, tyramine- $\mathrm{HCl}$, tryptamine- $\mathrm{HCl}$, octapamine- $\mathrm{HCl}$ and pargyline$\mathrm{HCl}$ were obtained from Sigma (St. Louis, USA), ascorbic acid, sodium periodate and sodium metabisulfite from Merck (Darmstadt, West Germany), catalase (specific activity : $65000 \mathrm{IU} / \mathrm{mg}$ ) from Boehringer (Mannheim, West Germany). Side-chain2-14 C-tyramine hydrochloride (specific activity: $50 \mathrm{mCi} / \mathrm{mmol}$ ) was obtained from the Radiochemical Centre (Amersham, England) and side-chain-2-14C-tryptamine bisuccinate (specific activity : $50 \mathrm{mCi} / \mathrm{mmol}$ ) from NEN (Dreieichenhain, West Germany).

Due to the limited number of samples and lack of sufficient knowledge as to how the considered enzyme activities were distributed in pigs, the data were analyzed using non-parametric statistics (Siegel, 1956).

\section{Results.}

Figure 1 illustrates the distribution of plasma DBH and platelet MAO activities in the different groups of pigs. Mean DBH activity was $66.55 \pm 2.27 \mathrm{nmol}$ of $\mathrm{p}$-hydroxy-

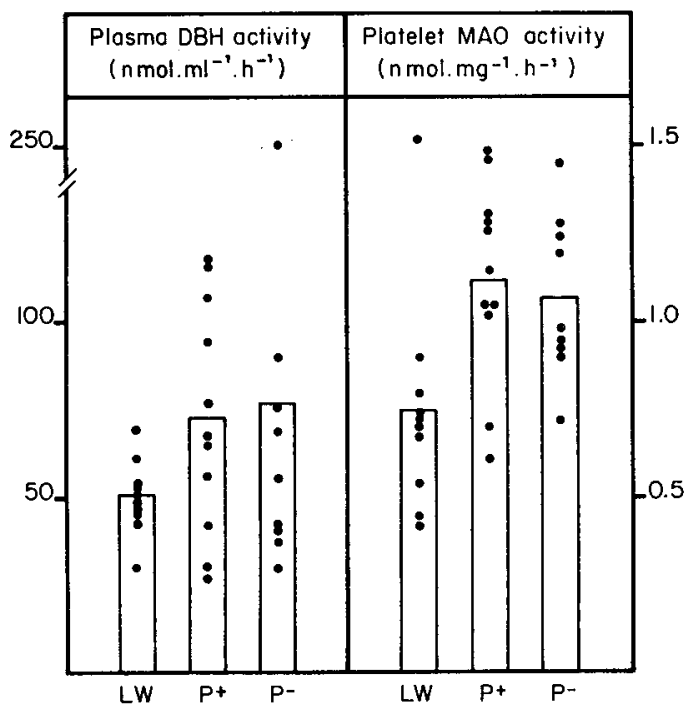

FIG. 1. - Plasma DBH activity and platelef MAO activity in a strain of Large-White (LW) an Piétrain pigs susceptible $(\mathrm{P}+)$ or not $(\mathrm{P}-)$ to malignant hyperthermia. Each point represents an individual value. The height of the column indicates the mean value for each group. 
benzaldehyde formed per $\mathrm{ml}$ of plasma per hour. One pig belonging to the $\mathrm{MH}$-nonsusceptible Piétrain group had an extremely high plasma DBH activity value (251 $\mathrm{nmol})$. We have no reasonable explanation for this finding, except that it might have been an unusual reaction to handling for blood sampling. In any case, discarding this extreme value lowered mean $\mathrm{DBH}$ activity of the $\mathrm{MH}$-non-susceptible Piétrain pigs from 76.96 to 55.22 , but had no effect on the results of between-group comparison (Kruskal-Wallis one-way analysis of variance : $\mathrm{H}=2.13$; d.f. $=2 ; \mathrm{P}>0.30$ when the extreme value was included $; \mathrm{H}=2.77$; d.f. $=2 ; \mathrm{P}>0.20$ when this value was discarded.) DBH activity was not sex-dependent (Mann-Whitney $U$ test : $U=112$; $\mathrm{n}_{1}=14 ; \mathrm{n}_{2}=16$ ).

Platelef MAO activity was lower in Large-White pigs than in Piétrain pigs $(H=8.61$; d.f. $=2 ; \mathrm{P}<0.02)$ but did not differ between $\mathrm{MH}$-susceptible and $\mathrm{MH}$ non-susceptible pigs. Both sexes had the same MAO activity $(U=105)$.

No correlation was found between plasma DBH activity and platelet MAO activity (Spearman rank correlation coefficient : $r_{\mathrm{s}}=0.05$ ).

\section{Discussion.}

No systematic study is available concerning platelet MAO and circulating DBH activities in pigs. The present findings indicate that the values of plasma DBH activity in pigs, as in other mammalian species (Nagatsu, 1977), are intermediate between rat and human values (Bouclier et al., 1977). There was no between-strain difference. This is in contrast with data reported in rats (Weinshilboum, 1979) but since only two strains of pigs were studied, we cannot speculate further on this difference.

Despite the vast literature on plasma DBH in both humans and rodents, the utility of the enzyme as a criterion of sympathetic nervous system function remains problematic (see Weinshilboum, 1979 for review). In the experiment reported here no attempt was made to validate the meaning of circulating DBH activity; the main objective was to determine if $\mathrm{MH}$ susceptibility was associated with different plasma $\mathrm{DBH}$ activities before further investigating the functional meaning of the observed difference.

Platelet MAO activities measured in pigs were somewhat lower than those found in healthy humans (1.4 to $9.9 \mathrm{nmol}$ of ${ }^{14} \mathrm{C}$-deaminated product per $\mathrm{mg}$ of platelet protein per hour) (Winter et al., 1978). MAO is believed to occur in two different forms, MAO-A and MAO-B, differing from selective inhibitors by their substrate affinity and sensitivity (Murphy, 1978). Sympathetic neurons contain predominantly MAO-A and blood platelets predominantly MAO-B. Since these two forms are relatively independent, the significance of platelet MAO activity as a criterion of catecholaminergic function has been questioned. While this significance is contraversial, it is less pronounced in pigs in which the MAO-B type predominates in most tissues, including the brain (Stranton ef al., 1975).

Genetic factors contribute to interindividual differences in platelet MAO activity which, different from plasma DBH activity, is not sensitive to short-term change (Murphy, 1978 ; Winter et al., 1978 ; Pandey ef al., 1979). Altered platelet MAO activities have been described in patients with mental disorders or subjects predisposed to psychiatric symptoms (Murphy and Wyatt, 1972 ; Leckman et al., 1977 ;Orsulak et al., 
1978). In monkeys platelet MAO activity correlated significantly with behavioral traits (Redmond et al., 1979). In the present case, it should be noted that Large-White pigs which had reduced platelet MAO activity displayed less ability to initiate active response when confronted with aversive events than Piétrain pigs which had higher platelet MAO activity (Dantzer and Mormède, 1978). However, more study is needed before we can speculate further on the relationship between these MAO activity differences and behavioral differences. More important at present is the finding that $\mathrm{MH}$ susceptibility is not associated with different platelet MAO activities. This result, combined with similarities in plasma DBH activity, casts some doubt on the hypothesis of the primary involvement of the sympathetic nervous system in the $\mathrm{MH}$ condition of pigs.

Reçu en juin 1980.

Accepté en septembre 1980.

Acknowledgements. - Many thanks are due to D. Aunis and D. Thierse (Centre de Neurochimie du CNRS, Strasbourg) for their help with the DBH assay and to P. Sellier (INRA, Dept. of Animal Genetics) for halothane-screening the pigs. This study received financial support from INRA, Pathologie animale and from the DGRST (grant no 7870680).

Résumé. L'activité de la DBH plasmatique et de la MAO plaquettaire a été mesurée par technique radioenzymatique chez 10 porcs Large White et 20 porcs Piétrain âgés de 9 à 11 semaines. Les porcs de Piétrain ont été classés en sensibles et en non sensibles au syndrome d'hyperthermie maligne, d'après leur réaction au test à l'halothane. Les porcs Large White utilisés ne sont pas sensibles à ce syndrome.

L'activité de la DBH plasmatique n'est influencée ni par la race ni par la sensibilité à l'halothane. L'activité de la MAO plaquettaire est plus faible chez les porcs Large White que chez les Piétrains; chez ces derniers, il n'y a pas de différence suivant le mode de réactivité à l'halothane.

Les résultats obtenus suggèrent que la prédisposition au syndrome d'hyperthermie maligne n'est pas liée à un dysfonctionnement du système nerveux sympathique.

\section{References}

ALTHEN T. G., ONO K., TOPEL D. G., 1977. Effect of stress susceptibility or stunning method on catecholamine levels in swine. J. anim. Sci., 44, 985-989.

BOUCLIER M., MANDEL P., AUNIS D., 1977. Microdetermination of dopamine- $\beta$-hydroxylase activities using a simplified, single-siep radioenzymatic assay. Pharmacol. Res. Comm., 9,743754.

CHEAH K. S., CHEAH A. M., 1976. The trigger for PSE conditions in stress susceptible pigs. J. Sci. Food Agric., 27, 1137-1144.

DANTZER R., MORMĖDE. P., 1978. Behavioural and pituitary-adrenal characteristics of pigs differing by their susceptibility to the malignant hyperthermia syndrome induced by halothane anesthesia. 1. Behavioural measures. Ann. Rech. vêt., 9, 559-567.

DANTZER R., MORMĖDE P., 1979. Le stress en élevage intensif. Masson, Paris.

GEFFEN L., 1974. Serum dopamine- $\beta$-hydroxylase as an index of sympathetic function. Life Sci., 14, 1593-1604.

LECKMAN J. F., GERSHON E. S., NICHOLS A. S., MURPHY D. L., 1977. Reduced MAO activity in first degree relatives of individuals with bipolar affective disorders. Arch. gen. Psychiat., 34, 601-608. 
LUCKE J. N., HALL G. M., LISTER D., 1979. Malignant hyperthermia in the pig and the role of stress. Ann. N. Y. Acad. Sci., 317, 326-337.

MORMĖDE P., DANTZER R., 1978. Behavioural and pituitary-adrenal characteristics of pigs differing by their susceptibility to the malignant hyperthermia syndrome induced by halothane anesthesia. II. Pituitary-adrenal function. Ann. Rech. vét., 9, 569-576.

MURPHY D. L., 1978. Substrate-selective monoamine oxidases. Inhibibitor, tissue, species and functional differences. Biochem. Pharmacol., 27, 1889-1893.

MURPHY D. L., WYATT R. J., 1972. Reduced monoamine oxidase activity in blood platelets from schizophrenic patients. Noture, 238, 225-226.

NAGATSU T., 1977, Dopamine- $\beta$-hydroxylase in blood and cerebrospinal fluid. Trends biochem. Sci., 2, 217-219.

OLLIVIER L., SELLIER P., MONIN G., 1975. Déterminisme génétique du syndrome d'hyperthermie maligne chez le Porc de Piétrain. Ann. Génét. Sélec. onim., 7, 159-166.

ORSULAK P. J., SCHILDKRAUT J. J., SCHATZBERG A. F., HERZOG J. M., 1978. Differences in platelet monoamine oxidase activity in subgroups of schizophrenics and depressive disorders. Biol. Psychiat., 13, 637-647.

PANDEY G. N., DORUS E., SHAUGHNESSY R., DAVIS J. M., 1979. Genetic control of platelet monoamine oxidase activity : studies on normal families. Life Sci., 25, 1173-1178.

REDMOND E., Jr., MURPHY D. L., BAULU J., 1979. Platelef monoamine oxidase activity correlates with social affiliative and agonistic behaviors in normal rhesus monkeys. Psychosom. Med., 41, 87-100.

SIEGEL S., 1956. Nonparametric statistics for the behavioral sciences. McGraw-Hill, New York.

STANTON H. C., CORNEJO R. A., MERSMANN H. J., BROWN L. J., MUELLER R. L., 1975. Ontogenesis of monoamine oxidase and catechol-O-methyl-transferase in various tissues of domestic swine. Arch. int. Pharmacodyn., 213, 128-144.

STOLK J. M., HURST J. H., VAN RIPER D. A., HARRIS P. Q., 1979. Genetic analysis of serum dopamine-beta-hydroxylase activity in rats. Molec. Pharmacol., 16, 922-931.

WEINSHILBOUM R. M., 1979. Serum dopamine- $\beta$-hydroxylase. Pharmacol. Rev., 30, 133-166.

WILLIAMS C. H., HOECH G. P., ROBERTS J. T., 1978. Experimental malignant hyperthermia. Anesthesiology, 49, 58-59.

WINTER H., HERSCHEL M., PROPPING P., FRIEDL W., VOGEL F., 1978. A twin study on three enzymes (DBH, COMT, MAO) of catecholamine metabolism. Psychopharmacology, 57, 63-69.

WURTMAN R. J., AXELROD J., 1963. A sensitive specific assay for the estimation of monoamine oxidase. Biochem. Pharmacol., 12, 1439-1440. 